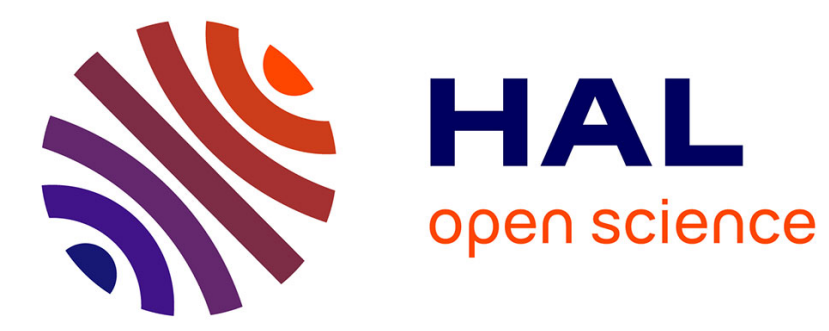

\title{
Anorogenic plateau formation: The importance of density changes in the lithosphere
}

Erik Duesterhoeft, Romain Bousquet, Henry Wichura, Roland Oberhänsli

\section{To cite this version:}

Erik Duesterhoeft, Romain Bousquet, Henry Wichura, Roland Oberhänsli. Anorogenic plateau formation: The importance of density changes in the lithosphere. Journal of Geophysical Research: Solid Earth, 2012, 117, pp.B07204. 10.1029/2011JB009007 . insu-00725599

\section{HAL Id: insu-00725599 \\ https://hal-insu.archives-ouvertes.fr/insu-00725599}

Submitted on 28 Feb 2013

HAL is a multi-disciplinary open access archive for the deposit and dissemination of scientific research documents, whether they are published or not. The documents may come from teaching and research institutions in France or abroad, or from public or private research centers.
L'archive ouverte pluridisciplinaire HAL, est destinée au dépôt et à la diffusion de documents scientifiques de niveau recherche, publiés ou non, émanant des établissements d'enseignement et de recherche français ou étrangers, des laboratoires publics ou privés. 


\title{
Anorogenic plateau formation: The importance of density changes in the lithosphere
}

\author{
Erik Duesterhoeft, ${ }^{1}$ Romain Bousquet, ${ }^{1,2}$ Henry Wichura, ${ }^{1}$ and Roland Oberhänsli ${ }^{1}$ \\ Received 8 November 2011; revised 24 May 2012; accepted 26 May 2012; published 17 July 2012.
}

[1] Away from active plate boundaries the relationships between spatiotemporal variations in density and geothermal gradient are important for understanding the evolution of topography in continental interiors. In this context the classic concept of the continental lithosphere as comprising three static layers of different densities (upper crust, lower crust, and upper mantle) is not adequate to assess long-term changes in topography and relief in regions associated with pronounced thermal anomalies in the mantle. We have therefore developed a one-dimensional model, which is based on thermodynamic equilibrium assemblage computations and deliberately excludes the effects of melting processes like intrusion or extrusions. Our model calculates the "metamorphic density" of rocks as a function of pressure, temperature, and chemical composition. It not only provides a useful tool for quantifying the influence of petrologic characteristics on density, but also allows the modeled "metamorphic" density to be adjusted to variable geothermal gradients and applied to different geodynamic environments. We have used this model to simulate a scenario in which the lithosphere-asthenosphere boundary is subjected to continuous heating over a long period of time (130 Ma), and demonstrate how an anorogenic plateau with an elevation of $1400 \mathrm{~m}$ can be formed solely as a result of heat transfer within the continental lithosphere. Our results show that, beside dynamic topography (of asthenospheric origin), density changes within the lithosphere have an important impact on the evolution of anorogenic plateaus.

Citation: Duesterhoeft, E., R. Bousquet, H. Wichura, and R. Oberhänsli (2012), Anorogenic plateau formation: The importance of density changes in the lithosphere, J. Geophys. Res., 117, B07204, doi:10.1029/2011JB009007.

\section{Introduction}

[2] Cenozoic plateaus, high-elevation, low-relief regions of great areal extent, occur in a variety of geodynamic environments and present first-order topographic features that exert an important influence on atmospheric circulation patterns, the distribution of rainfall, erosion, sediment transport, depositional processes, and sediment storage [Molnar et al., 1993; Allmendinger et al., 1997; Strecker et al., 2007]. Plateau regions often record changes in fault activity through time, where shortening is superseded by extension, often accompanied by changes in magmatic character [Montero Lopez et al., 2010]. In addition, with elevations ranging between approximately 1500 and $5000 \mathrm{~m}$, plateaus impact biodiversity. Many recent studies highlight the effect of plateau uplift on

\footnotetext{
${ }^{1}$ Institute of Earth and Environmental Science, University of Potsdam, Potsdam, Germany.

${ }^{2}$ Now at Geosciences Rennes, UMR 6118, CNRS, University of Rennes 1 , Rennes, France.

Corresponding author: E. Duesterhoeft, Institute of Earth and Environmental Science, University of Potsdam, Karl-Liebknecht-Str. 2425, 14476 Potsdam, Germany. (Erik.Duesterhoeft@geo.uni-potsdam.de)

(C2012. American Geophysical Union. All Rights Reserved. 0148-0227/12/2011JB009007
}

climate and precipitation patterns [e.g., Molnar et al., 1993; Hay et al., 2002; Sepulchre et al., 2006], while other investigations have focused on the possible underlying plateaubuilding mechanisms [e.g., McKenzie, 1984; Le Pichon et al., 1997; Henry et al., 1997; Allmendinger et al., 1997; Hetényi et al., 2007]. Despite many unifying characteristics of plateaus in different geodynamic settings, two plateau endmember types can be distinguished: (1) high-elevation plateaus, which are related to orogenic processes in collisional or non-collisional geodynamic settings (e.g., Tibet, Altiplano-Puna, Central and Eastern Anatolia/Iran), and (2) lower, anorogenic plateaus typically reaching elevations of approximately $1500 \mathrm{~m}$ (e.g., South Africa, East Africa, Mongolia), inferred to be closely linked to mantle plumes away from plate boundaries [Hartnady, 1985; Ebinger and Sleep, 1998; Burke and Gunnel, 2008].

[3] In this study we address the issue of anorogenic plateau formation. How thermal and dynamic processes associated with mantle plumes result in plateaus and long-wavelength topography has, as yet, not been unambiguously established. This is at least partly because the viscosity structure of the asthenosphere remains largely unknown, particularly beneath East Africa [e.g., White and McKenzie, 1989; Prodehl et al., 1994; Huerta et al., 2009] and South Africa [e.g., Lithgow-Bertelloni and Silver, 1998; Gurnis et al., 
a Mechanical response: shoulder uplift

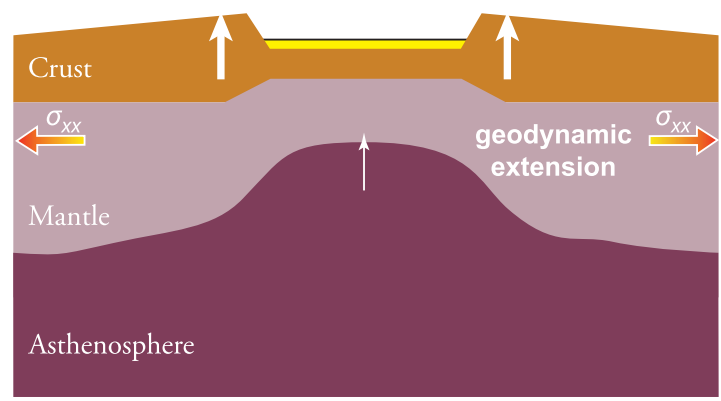

Syn-rift uplift

\section{c Lithospheric delamination}

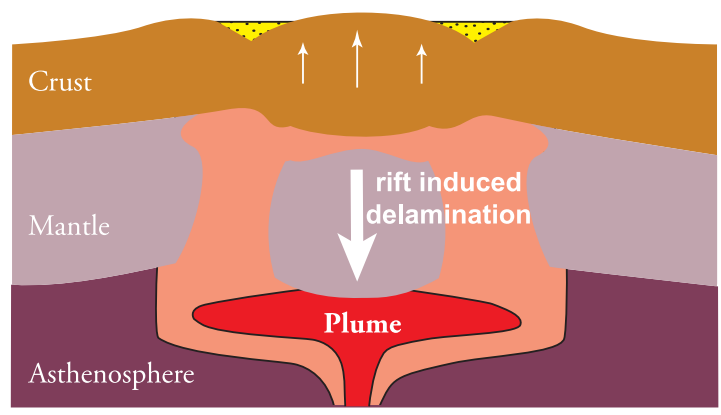

Syn-rift uplift b Mantle plume impingement

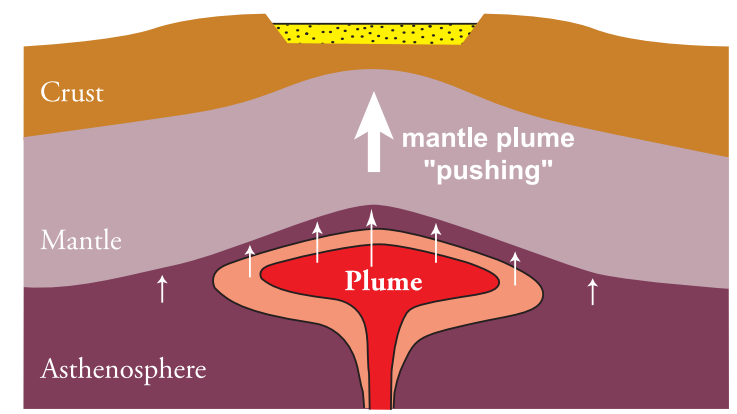

Syn-rift uplift

\section{d Lithospheric thermal expansion}

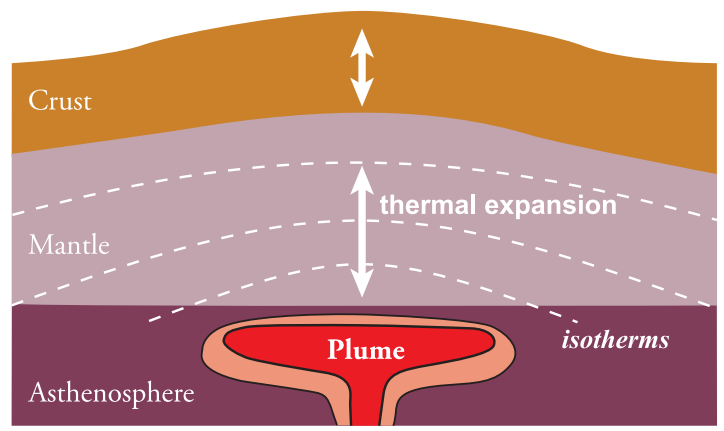

Not rift-related

Figure 1. Review of models for anorogenic plateau formation proposed in published literature. Here, the first three models are rift-related: (a) in the shoulder uplift model [Braun and Beaumont, 1989] the plateau formation is a mechanical response to extension within the lithosphere, while (b) mantle impingement results from mechanical uplift of the lithosphere by a mantle plume push [Ebinger et al., 1989], and (c) delamination of the lithospheric mantle is induced by two merging rift tips [Wallner and Schmeling, 2010] and is synchronous with the rifting processes (pink area illustrates area of temperature anomalies and upwelling asthenospheric material). Finally, (d) the last model assumes plateau formation due to thermal expansion as a response to a temperature change at the lithosphere-asthenosphere boundary (LAB) [Wichura et al., 2011].

2000]. Despite these problems, present-day topographic variations in anorogenic plateau realms (mostly associated with mantle plume and/or rifting) are generally explained by three different geodynamic models: (1) syn-rift shoulder uplift resulting from denudation [e.g., Braun and Beaumont, 1989; Weissel and Karner, 1989] (Figure 1a); (2) the development of dynamic topography resulting from the mantle-plume impingement on continental lithosphere and convection processes in the asthenosphere [Ebinger et al., 1989] (Figure 1b); and (3) delamination of mantle lithosphere and ensuing isostatic uplift [Wallner and Schmeling, 2010] (Figure 1c). However, all these models do not include the effect of lithospheric thermal expansion [Wichura et al., 2011] (Figure 1d) that could be added as a fourth model or process.

[4] In the first model, which involves an active rifting scenario, a wide and extensional basin acts as a negative load, which causes the lithosphere to rise. Both, denudation and the subsequent elastic response ultimately lead to riftshoulder uplift (Figure 1a). Second, the impingement model involves hot buoyant mantle material, which forms a plume that is less dense than the surrounding continental lithosphere and therefore rises through it. The continental lithosphere is thinned and heated by the plume head, and the combined effect of thinned lithosphere and less dense material within the plume results in crustal uplift (Figure 1b). The third (delamination) model involves detachment of the relatively cool and dense lower lithosphere from the upper lithosphere and its replacement by hotter, less dense asthenosphere. The removal of cool lithosphere results in isostatic rebound (Figure 1c). Alternatively, this paper investigates the effect of lithospheric thermal expansion as proposed by Wichura et al. [2011]. In contrast to the first three models, lithospheric thermal expansion is not necessarily rift-related and occurs long before onset of rifting (Figure 1d). Importantly, all these geodynamic models are based on disturbance of the lithospheric layering through time and thus require a good understanding of the density distribution within the continental lithosphere in order to derive geodynamic models for anorogenic plateau formation. However, it is not well known, how and to what degree the four geodynamic models may interact. We hypothesize that heating processes at the 
lithosphere-asthenosphere boundary (LAB) [see Fischer et al., 2010] caused by a mantle plume is a key process that drives uplift and the generation of long-wavelength topography. Based on this hypothesis and assuming a stable LAB, we compute the density distribution along a one-dimensional depth-profile (using two different methods of calculation with and without mineral reactions) as a function of volume, temperature, and pressure. Furthermore, in order to better understand the temporal characteristics of mantle-plume heat transfer and its topographic response, we calculate the time span required to generate significant topographic uplift.

\section{Methodology}

[5] In order to address the question of how the density of the continental lithosphere changes if the lithosphereasthenosphere boundary is heated, we consider a threelayered continental lithosphere comprising the upper crust, lower crust, and lithospheric mantle (as many studies assumed) [e.g., Unglert et al., 2011] and a stable LAB (resistant to alteration, thinning and thickening of the lithosphere). We assume constant thicknesses of $150 \mathrm{~km}$ for the lithosphere [Artemieva, 2006] and $35 \mathrm{~km}$ for the crust [Christensen and Mooney, 1995], which are typical for Europe and East Africa [Mooney et al., 1998]. Both, the upper and lower crust are taken to be $17.5 \mathrm{~km}$ thick [e.g., Rudnick and Fountain, 1995]. These thicknesses are assumed to be constant over the entire calculation; volume changes or stretching processes are thus not taken into account. The chemical compositions chosen for a water-saturated felsic upper crust are from Taylor and McLennan [1985], those for a water-saturated mafic lower crust from Rudnick and Fountain [1995], and a dry lherzolite composition for the lithospheric mantle from Brown and Musset [1993], corresponding to the phase diagram of Schmidt and Poli [1998]. A dry lithospheric mantle beneath cratonic regions is inferred from xenoliths of early stage volcanic activities (e.g., African cratons) [Lee and Rudnick, 1999; Chesley et al., 1999; Ayalew et al., 2009; Katayama and Korenaga, 2011].

[6] Accordingly, we calculate a geotherm with the onedimensional (vertical) heat equation

$$
\frac{\partial T}{\partial t}=\kappa \frac{\partial^{2} T}{\partial z^{2}}+\frac{A_{0}}{\rho c_{p}}
$$

where $T$ is temperature, $t$ is time, and $z$ is depth. The coefficient $\kappa=k /\left(\rho^{*} c_{p}\right)$ is called the thermal diffusivity and is taken to be constant over the entire range of the model $(\kappa=$ $\left.1^{*} 10^{-6} \mathrm{~m}^{2} / \mathrm{s}\right)$. Furthermore, $c_{p}$ is the specific heat capacity, $k$ is the conductivity, $\rho$ is the density, and $A_{0}$ is the heat production per unit volume of the medium. $A_{0}$ and $k$ are taken to be constant throughout each of the three layers, respectively. Using the finite difference method, the thermal equation is stable if the Fourier Modulus $(F o)$ is equal to $\kappa^{*}\left(\mathrm{n} / \mathrm{m}^{2}\right) \leq 0.5$ (where $m$ is the length scale of interest and $n$ is the characteristic timescale). The surface temperature is taken to be $0^{\circ} \mathrm{C}$ and the temperature at the LAB is chosen as the lower boundary condition. The initial reference temperature at the $\mathrm{LAB}$ is $1350^{\circ} \mathrm{C}$ [Jaupart et al., 1998; Jaupart and Mareschal, 2011]. In order to model the increase in temperature due to a rising plume we raise the basal temperature at the $\mathrm{LAB}$ to $1600^{\circ} \mathrm{C}$ and $1800^{\circ} \mathrm{C}$
[Farnetani, 1997; Thompson and Gibson, 2000]. The resultant geotherms are shown in Figure 2a.

[7] Density determination requires the corresponding lithostatic pressure $\mathrm{P}_{\text {lith }}$, which is calculated iteratively using the equation

$$
P_{\text {lith }}=\rho \cdot g \cdot h+P_{0}
$$

where $\rho$ is the density, $g$ is acceleration of gravity, $h$ is layer thickness and $P_{0}$ is surface pressure. In order to understand the effects of temperature change and heat propagation within the continental lithosphere and their feedback with surface uplift, we test two different approaches to modeling density and topographic changes.

[8] In the first approach we calculate a (here called) "physical density" by applying the method commonly used in the literature [e.g., Turcotte and Schubert, 2002; Pascal, 2006], in which density changes with temperature and pressure and follows the equation

$$
d \rho=\rho \beta d P-\rho \alpha d T
$$

where $\alpha$ is the coefficient of thermal expansion, $\beta$ is the isothermal compressibility; $\rho$ is the initial density; $\mathrm{d} T$ is the temperature change, $\mathrm{d} P$ is the pressure change, and $\mathrm{d} \rho$ is the change in density for each step (every $500 \mathrm{~m}$ ). Each layer is thus treated as a homogeneous body in which the physical properties $(\alpha, \beta)$ remain constant with depth and time (see also supplementary material: Table A1).

[9] In the second approach we determine the density by taking into account the mineralogical changes that occur with changes in temperature and/or pressure [Richardson and England, 1979]. We therefore calculate a (here called) "metamorphic density" as a function of temperature, pressure, and chemical composition [Bousquet et al., 1997] and model the changes in "metamorphic density" and physical properties using the principle of minimized ("apparent") Gibbs free energy $\Delta_{a} G$ [de Capitani and Brown, 1987] according to

$$
\Delta_{a} G=\Delta_{f} H^{0}+\int_{T_{0}}^{T} c_{p} d T-T \cdot S^{0}-T \cdot \int_{T_{0}}^{T} \frac{c_{p}}{T} d T+\int_{P_{0}}^{P} V d P
$$

where $\Delta_{f} H^{0}$ is enthalpy of formation, $S^{0}$ is the molar entropy, $V$ is the molar volume, $\mathrm{T}_{0}$ and $\mathrm{P}_{0}$ is surface temperature and pressure. With increasing depth, temperature and pressure will also increase. For the "metamorphic density" calculations we used the Theriak/Domino software [de Capitani and Petrakakis, 2010], applying an updated thermodynamic database from Berman [1988] (JUN92.bs [see de Capitani and Petrakakis, 2010]). In addition to computing the stable assemblages at a specific temperature and pressure, the Theriak/Domino software also computes a variety of chemical and physical properties for these assemblages, such as the total solid phase density [Bousquet et al., 2005]. Furthermore, it is important to note that we do not consider the effects of melt production, storage, and extrusion since present databases are still lacking well-constrained thermodynamic data for melts. 


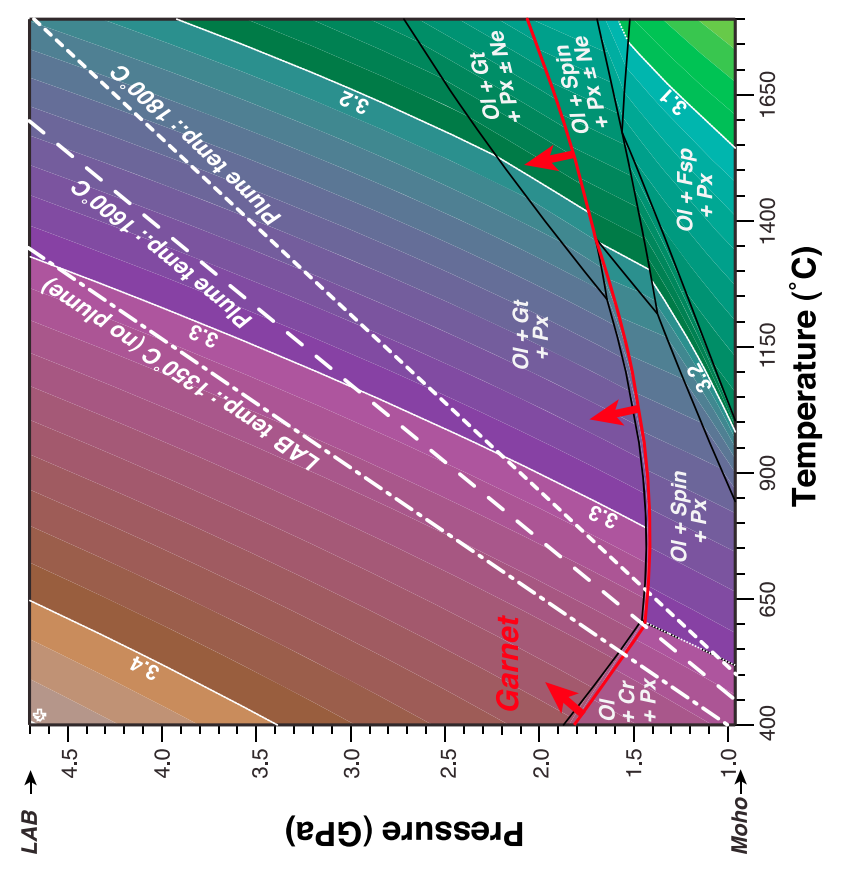

ㅇ

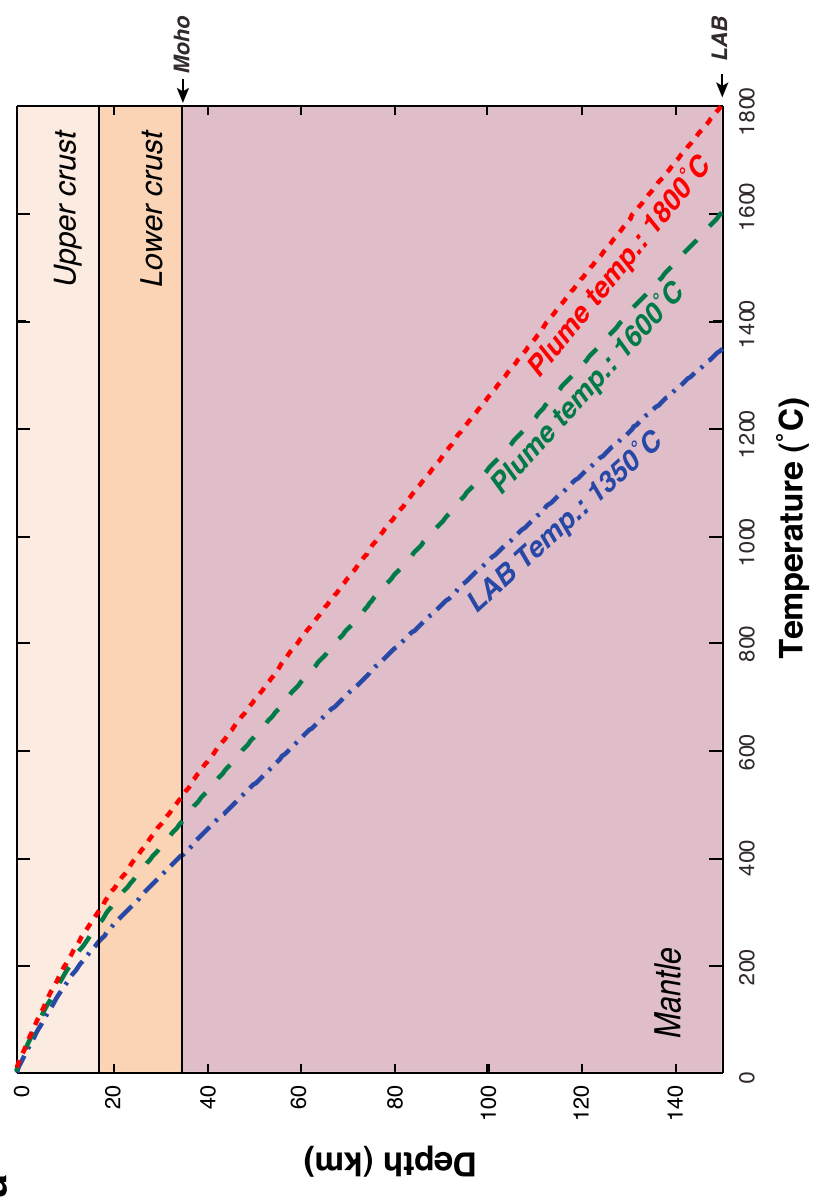

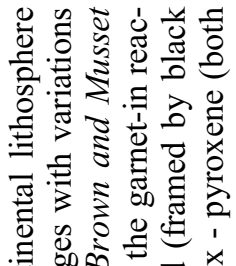

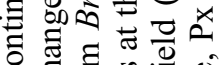
ठ ढ्र

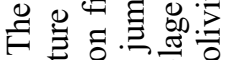
宛: :

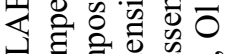

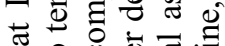
胥. 중

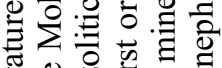

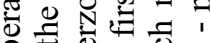
要芯芯

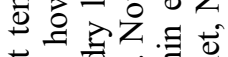

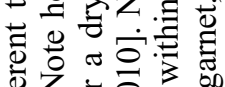

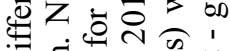

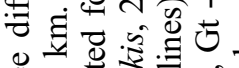

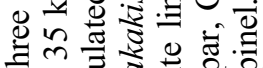

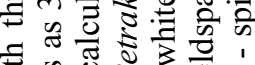

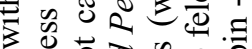
吾음 है

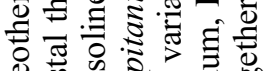

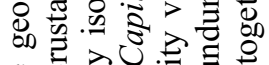
跑 क्ष心

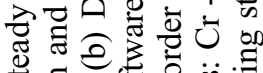
क छ

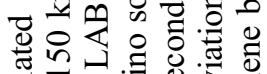

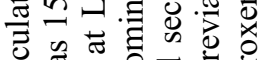

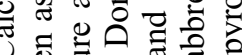

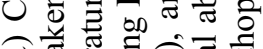

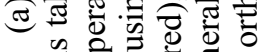

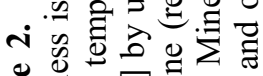

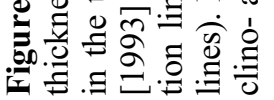


[10] First-order "metamorphic density" changes, for example for mantle rocks (Figure 2b), are controlled by mineralogical changes (e.g., the appearance of garnet), and second-order "metamorphic density" changes by physical $(\alpha, \beta)$ and chemical (molar ratio of minerals) processes. First-order processes result in abrupt changes of "metamorphic density" (jumps), while second-order processes affect the slope of the "metamorphic density" isolines in the PTfield (Figure 2b).

\section{Steady State Model}

[11] Before we discuss the effects of time variations, a steady state model is considered. The "physical" and "metamorphic density" paths were computed to obtain an overview of similarities and differences in the density-depth profiles (Figure 3). Using such a steady state model the temperature at the LAB does not have much effect on the "physical density" of the continental crust and only a limited influence on that of the continental lithospheric mantle. Moreover, the "physical density" remains approximately constant within each layer (Figure 3a). In contrast, the temperature at the LAB has a major influence on the distribution of mineral assemblages and the "metamorphic density" clearly varies within each layer (Figure 3c). Thus the classic three-layer composition model corresponds to a three-layer density profile when considering the "physical density" (Figure 3a). In contrast, the modeling of "metamorphic density" reveals up to six density steps (Figure 3c), so that a three-layer density model is no longer representative of the density distribution in the crust and lithosphere, because chemical reactions influence both, the stability of the mineral assemblages and the rock densities.

\subsection{Lithospheric Mantle}

[12] The "physical density" is mainly controlled by the ratio of pressure to temperature. For this reason a decrease in density reflects an increase of the plume temperature (Figure 3a). If the temperature only changes by about $+250^{\circ} \mathrm{C}$ at the LAB, only small pressure variations are visible. This results in a negative $\mathrm{d} \rho$ (see equation (3)). This effect is more clearly visible in the "metamorphic density" distribution (Figure 3c) because the superposition of "physical density" changes for particular minerals within a rock results in more marked density changes than considering only the bulk rock parameters.

[13] Dry mantle is usually composed of olivine (Ol), clino- (Cpx) and orthopyroxene (Opx), and an aluminumbearing phase (plagioclase (Fsp), spinel (Spin), garnet (Gt), or corundum $(\mathrm{Cr})$ ). Reactions that replace the aluminumbearing phase (e.g., spinel to garnet) are accompanied by a shift in density (Figure 2b). Along all three geotherms the upper part of the mantle contains a small amount of corundum ( $<3 \%$ of the total volume) representing the aluminumbearing phase [Morishita et al., 2007; Hattori et al., 2010]. For temperatures at the $\mathrm{LAB}$ of $1350^{\circ} \mathrm{C}$ and $1600^{\circ} \mathrm{C}$ the marked density increase at a pressure of $\sim 1.5 \mathrm{GPa}$ is due to the corundum-garnet transition (Figure $2 b$ ). This may sound counter intuitive because corundum has a higher density $\left(\sim 3.9 \mathrm{~g} / \mathrm{cm}^{3}\right)$ than garnet $\left(\sim 3.7 \mathrm{~g} / \mathrm{cm}^{3}\right)$. However, garnet absorbs additional magnesium from pyroxene (e.g., $2 \mathrm{Cr}+3$ $\mathrm{Opx}=2 \mathrm{Gt}$ ) and, as a result, the amount of pyroxene decreases significantly, while the relative proportion of garnet increases. The rock consequently contains much more garnet $\left(\mathrm{Mg}_{3} \mathrm{Al}_{2} \mathrm{Si}_{3} \mathrm{O}_{12}\right)$ than the initial amount of corundum $\left(\mathrm{Al}_{2} \mathrm{O}_{3}\right)$. On the other hand, the geotherm assuming a plume temperature of $1800^{\circ} \mathrm{C}$ cuts across the spinel stability field (Figure 2b). Spinel $\left(\mathrm{MgAl}_{2} \mathrm{O}_{4}\right)$ has a lower density than corundum and absorbs only one third as much magnesium as is absorbed by garnet. A decrease in density at the corundum-spinel transition (e.g., $2 \mathrm{Cr}+2 \mathrm{Ol}=2 \mathrm{Spin}+1$ $\mathrm{Opx}$ ) and an increase in density at the spinel-garnet transition (e.g., $1 \mathrm{Spin}+2 \mathrm{Opx}=1 \mathrm{Gt}+1 \mathrm{Ol}$ ) can therefore be recognized at pressures of $\sim 1.5 \mathrm{GPa}$. Therefore the stability of aluminum-bearing mineral phases in the lithospheric mantle has a major influence on the density distribution.

\subsection{Lower Crust}

[14] In cratonic shield areas temperatures within the lower crust are relatively cool. The Moho temperature ranges between $400^{\circ} \mathrm{C}$ (temperature at the $\mathrm{LAB}=1350^{\circ} \mathrm{C}$ ) and $550^{\circ} \mathrm{C}$ (plume temperature at the $\mathrm{LAB}=1800^{\circ} \mathrm{C}$ ), whereas temperatures at the lower-upper crust transition range between $250^{\circ} \mathrm{C}$ and $350^{\circ} \mathrm{C}$ (Figure 2a). Low geotherms, which are similar to those used in our model with a temperature at the $\mathrm{LAB}$ of $1350^{\circ} \mathrm{C}$, allow the stability of waterbearing minerals such as lawsonite.

[15] The "physical density" shows a gradual but continuous increase with depth (Figure 3a), whereas the "metamorphic density" records a significant jump $\left(+0.05 \mathrm{~g} / \mathrm{cm}^{3}\right)$ at a depth of $25 \mathrm{~km}$ for a temperature at the $\mathrm{LAB}$ of $1350^{\circ} \mathrm{C}$, at $20 \mathrm{~km}$ for $1600^{\circ} \mathrm{C}$, and at $18 \mathrm{~km}$ for $1800^{\circ} \mathrm{C}$ (Figure $3 \mathrm{c}$ ). This increase reflects a marked change in the quantity of water-bearing minerals (such as lawsonite, which is stable in the lower crust due to the low temperature conditions [Pognante, 1989]) and feldspar. It is, however, important to note that lawsonite and feldspar do not disappear completely. For example, during the reaction in which free fluid is released and feldspar disappears, the amount of lawsonite is reduced from $15 \%$ to $1 \%$, resulting in a density change of $+0.05 \mathrm{~g} / \mathrm{cm}^{3}$. Increasing the temperature at the LAB means that this reaction takes place at a shallower depth (Figure 3c) due to the fact that the lower crust is already warm and consists mostly of water-free minerals. Where the crust is warmer or thicker, with a Moho temperature of about $600^{\circ} \mathrm{C}$, the appearance of denser minerals such as garnet $\left(3.7 \mathrm{~g} / \mathrm{cm}^{3}\right)$ will result in considerable changes in rock density (see also supplementary material: Figure A1).

\subsection{Upper Crust}

[16] Temperatures in the upper crust of cratonic shield areas are generally low, ranging from 250 or $350^{\circ} \mathrm{C}$ down to $0^{\circ} \mathrm{C}$ at the surface, implying the stability of large quantities of water- or $\mathrm{OH}$-rich minerals (e.g., zeolites, micas, chlorites). Our calculations reveal that, where the temperatures at the LAB are high the "physical density" slightly decreases with depth (Figure 3a). In this case the density is strongly controlled by thermal expansion parameters (see equation (3)). In contrast, the "metamorphic density," in which phase transitions are taken into account, increases with depth within the upper crust (Figure 3c). Two factors are responsible for the "metamorphic density" distribution in the upper crust: first, the phase transitions, and second, thermal expansion within a constant mineral assemblage (as in the "physical density" 


\section{Physical density}
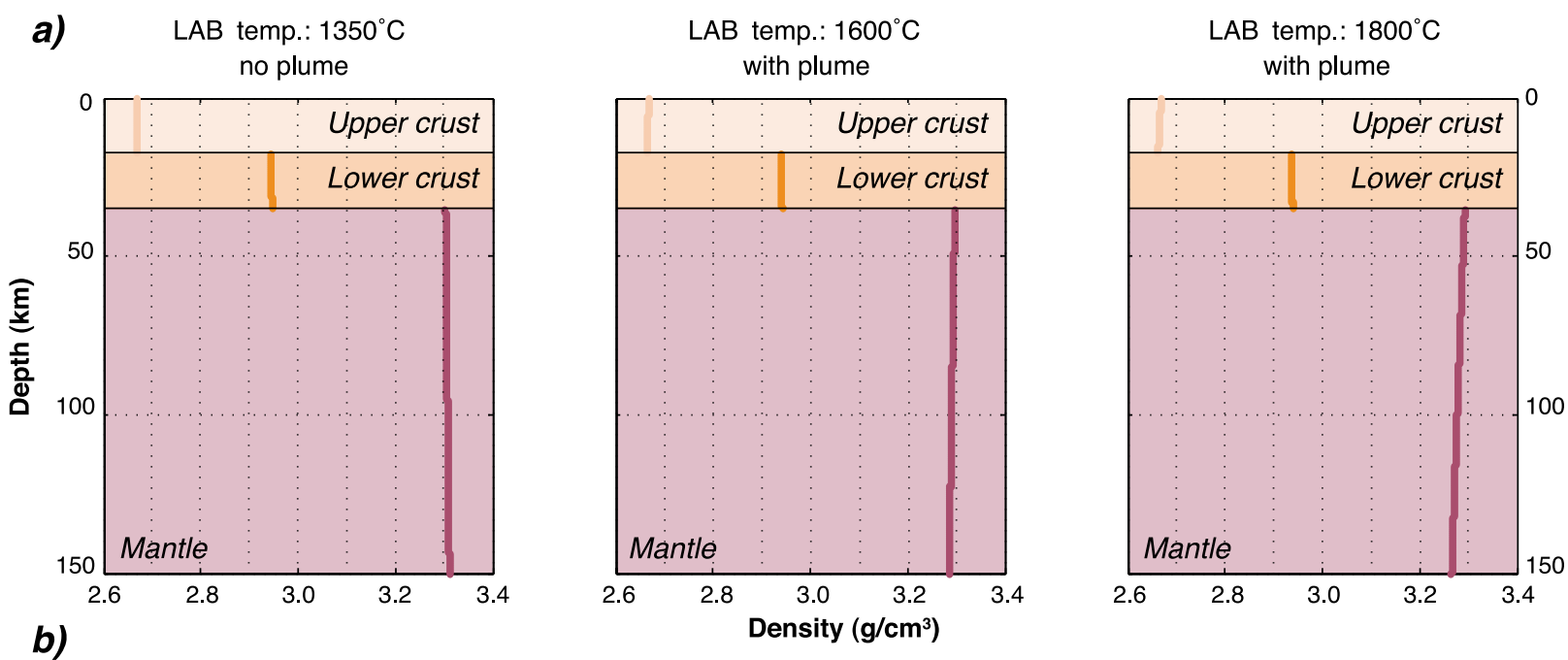

\section{b)}
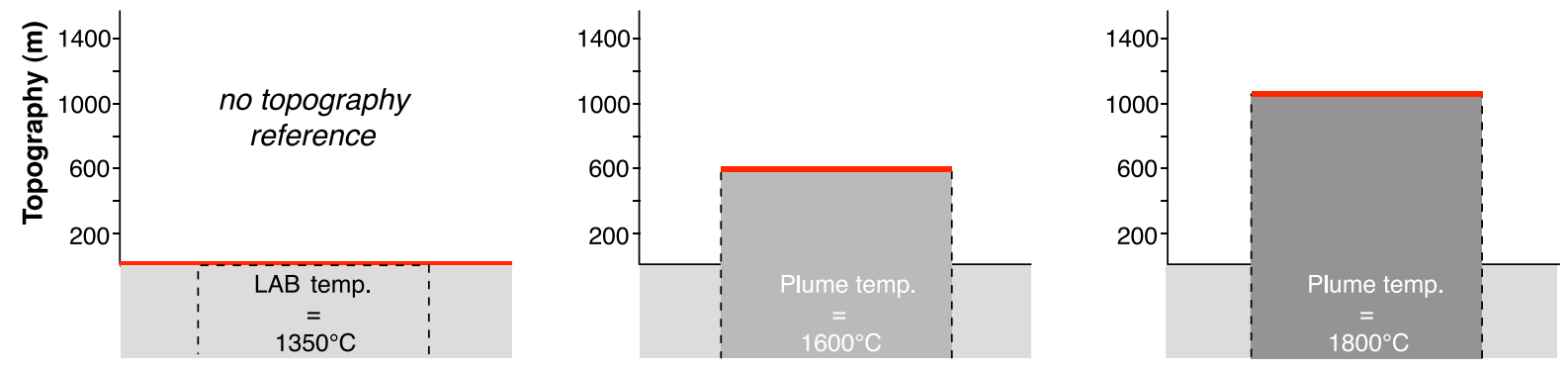

\section{Metamorphic density}

c) LAB temp.: $1350^{\circ} \mathrm{C}$

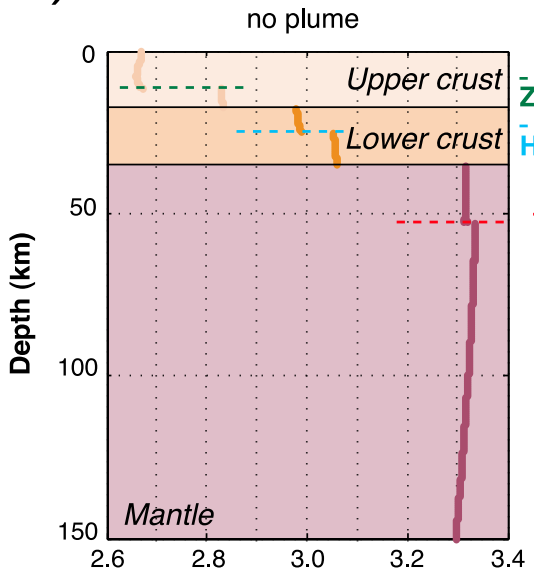

d)

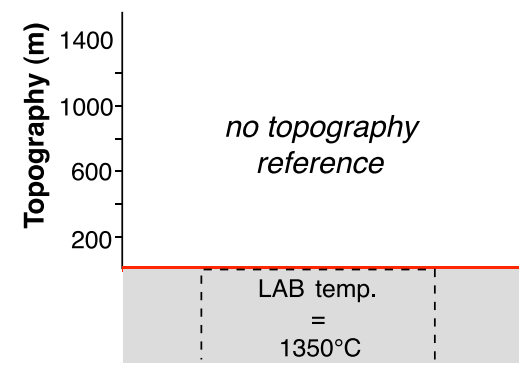

LAB temp.: $1600^{\circ} \mathrm{C}$

with plume
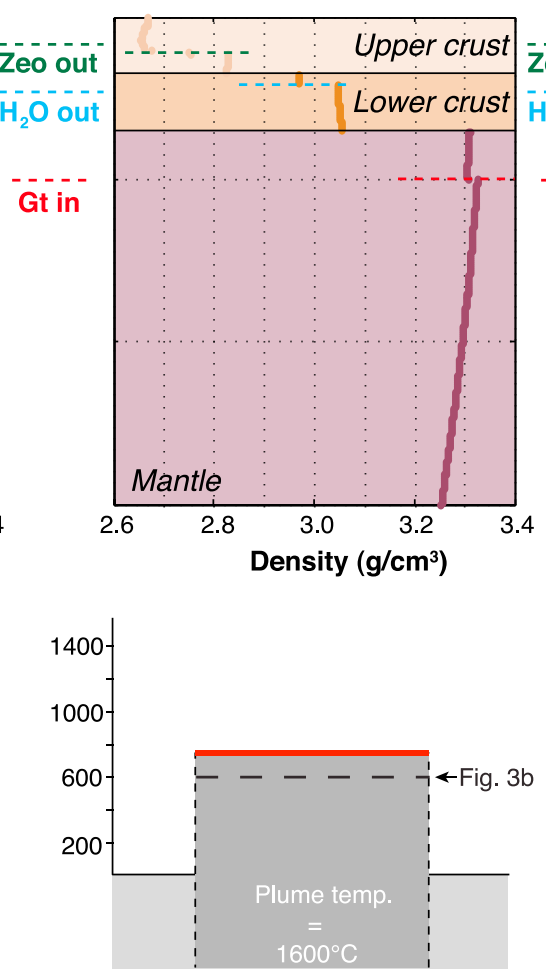

Figure 3
LAB Temp.: $1800^{\circ} \mathrm{C}$ with plume
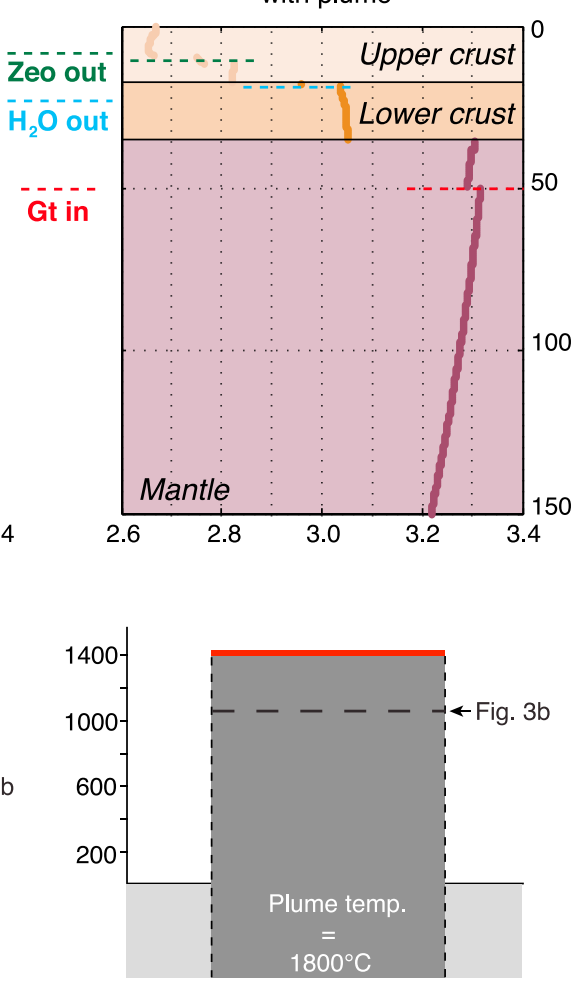
model) and the molar ratios of different mineral phases (Figure 3c). Changes in the mineral assemblage can produce a density increase in excess of $0.1 \mathrm{~g} / \mathrm{cm}^{3}$. The main density jump results from the zeolite (or illite) transition [e.g., Vidal and Dubacq, 2009], followed by a second jump (resulting from transition with lawsonite and/or epidote assemblages) for high temperatures. Both transitions are dehydration transitions that have a critical effect on rock density. The appearance of large quantities of minerals such as lawsonite or epidote increases the rock density due to their high mineral density $\left(3.1 \mathrm{~g} / \mathrm{cm}^{3}\right)$. A similar effect can be observed if light, $\mathrm{OH}$-bearing minerals are changed into heavier, water-free minerals. Such transitions are not dependent on the geothermal gradient because most dehydration transitions are isothermal and temperature increase will result in rocks of higher density (see also supplementary material: Figure A2).

\subsection{Summary}

[17] Steady state calculations clearly provide some interesting results. Increasing the temperature at the LAB leads to a decrease in the density of the lithospheric mantle and to an increase in the crustal density. However, because of the difference in thickness between the crust and the lithospheric mantle changes within the mantle will largely control the isostatic response to any temperature change at the LAB. Moreover, these important changes in density over a $150 \mathrm{~km}$ thick continental lithosphere must result in isostatic uplift (Figures $3 b$ and $3 d$ ). In order to estimate the amount of uplift that would result from heating at the $\mathrm{LAB}$ we used a $\mathrm{LAB}$ temperature of $1350^{\circ} \mathrm{C}$ as our reference temperature and set the initial surface elevation to zero. The change in elevation (using a standard Airy-type calculation) was found to be not only dependent on the temperature increase, but also on the model that was used to estimate the different types of density (physical and metamorphic). Thus raising the temperature at the $\mathrm{LAB}$ to $1600^{\circ} \mathrm{C}$ and $1800^{\circ} \mathrm{C}$ would induce uplift and result in plateau elevations of 600 and $1050 \mathrm{~m}$ respectively using the "physical density" model (Figure 3b), or 780 and $1400 \mathrm{~m}$ using the "metamorphic density" model (Figure 3d). The isostatic response is more striking using a standard Pratt-type calculation, resulting in a slightly higher uplift by a maximum difference of $30 \mathrm{~m}$. The difference between the Airy- and Pratt-type calculation is small relative to the total uplift.

\section{Time Dependent Density Model}

[18] Our calculations have provided a possible explanation for the formation of anorogenic plateaus in situations where the lithosphere is in full thermal equilibrium. The concept of topographic evolution over time as the result of a rising mantle plume heating the LAB is fundamental to understanding sedimentary records and thermochronology data. We therefore investigate both the density (Figures $4 \mathrm{a}$ and 4b) and topographic evolution (Figures $4 \mathrm{c}$ and $4 d$ ) over time by assuming a constant heat source that increased the initial temperature at $\mathrm{LAB}$ of $1350^{\circ} \mathrm{C}$ stepwise to $1600^{\circ} \mathrm{C}, 1800^{\circ} \mathrm{C}$, and $2000^{\circ} \mathrm{C}$. Due to the diffusive nature of heat transport, a long period of time $(500 \mathrm{Ma})$ is required to achieve the steady thermal state required for thermal and topographic equilibration. In this respect, each individual time step demonstrates how heat from below affects the lithosphere. The mantle is first heated to extreme temperatures and the density decreases rapidly. In a later but less effective stage, the crust is also affected by heating and density variations.

[19] Isostatic response that is expressed by plateau building and results from density changes at depth, strongly depends on the used type of density calculations used (physical versus metamorphic) and the temperature at the LAB. If we assume the initial topography to be zero and the plume temperature at the LAB to be $1800^{\circ} \mathrm{C}$, using "metamorphic density" calculations suggests an uplift of approximately $1400 \mathrm{~m}$ attained after $500 \mathrm{Ma}$ (Figure 4d). This is in contrast to an uplift of only $1050 \mathrm{~m}$ if "physical density" variations are used (Figure 4c). In addition, whereas the time required to reach $50 \%$ of the final uplift (29 to 36 Ma for the "physical density" model and 25 to 29 Ma for the "metamorphic density" model) or $75 \%$ of the uplift (76 to $88 \mathrm{Ma}$ for the "physical density" model, and 62 to $75 \mathrm{Ma}$ for the "metamorphic density" model) of the final topography is consistent, the time required to reach $90 \%$ of the final topography is highly dependent on the plume temperature in the "metamorphic density" model (Figure 4d). Steady state calculations show that the uplift is mainly controlled by density changes in the lithospheric mantle, while the time-dependent calculations reveal that although the mantle contribution is important for the early development of topography, the response of the crust (due to increasing of "metamorphic density") to increasing temperatures can delay the final topographic evolution.

[20] For example to build-up an anorogenic plateau of about $1400 \mathrm{~m}$ height, similar to the East African Plateau or the South African Plateau, the "physical density" model would require unrealistic temperatures at the $\mathrm{LAB}$ of about $2000^{\circ} \mathrm{C}$. Such temperatures are unlikely since the temperatures of plume heads are thought to be generally below or about $1800^{\circ} \mathrm{C}$ [Farnetani, 1997; Thompson and Gibson, 2000]. Assuming a temperature range up to $1800^{\circ} \mathrm{C}$, the "metamorphic density" model is in good agreement with the elevation of anorogenic plateaus.

\section{Discussion and Conclusion}

[21] Although our model is a first-order attempt to assess density changes in the topographic evolution of anorogenic plateaus, the results are very instructive and suggest considerable primary synthermal uplift as a viable mechanism for anorogenic plateau formation. The calculated time required

\begin{abstract}
Figure 3. Calculated steady state density profiles along an average PT-path for the continental lithosphere (see Figure 2a). LAB is the lithosphere-asthenosphere boundary at $150 \mathrm{~km}$ depth. (a) Physical density calculated as function of pressure, temperature, initial density, and constant thermal expansion and compressibility for each layer. (b) Isostatic response to each calculated physical density-depth profile. (c) Metamorphic density calculated as function of pressure, temperature, and composition. Dashed lines display important mineral reactions. Abbreviations: $\mathrm{Gt}$ - garnet, $\mathrm{H}_{2} \mathrm{O}$ - water, Zeo - zeolites. (d) Isostatic response to each calculated metamorphic density-depth profile. The topographic elevations resulting from metamorphic density calculations are higher than those derived from physical density calculations for the same temperature at LAB.
\end{abstract}




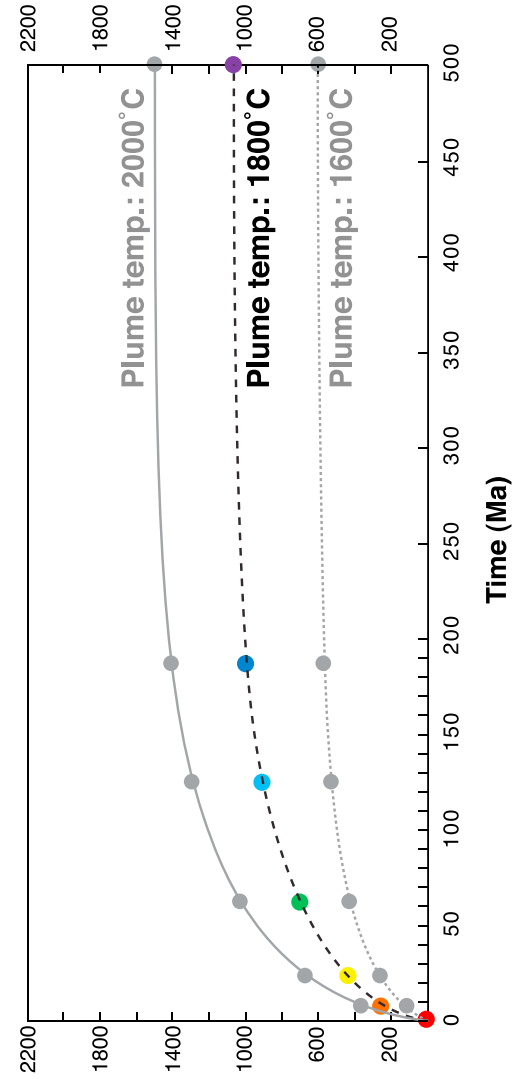

0

(u) Kydes6odol

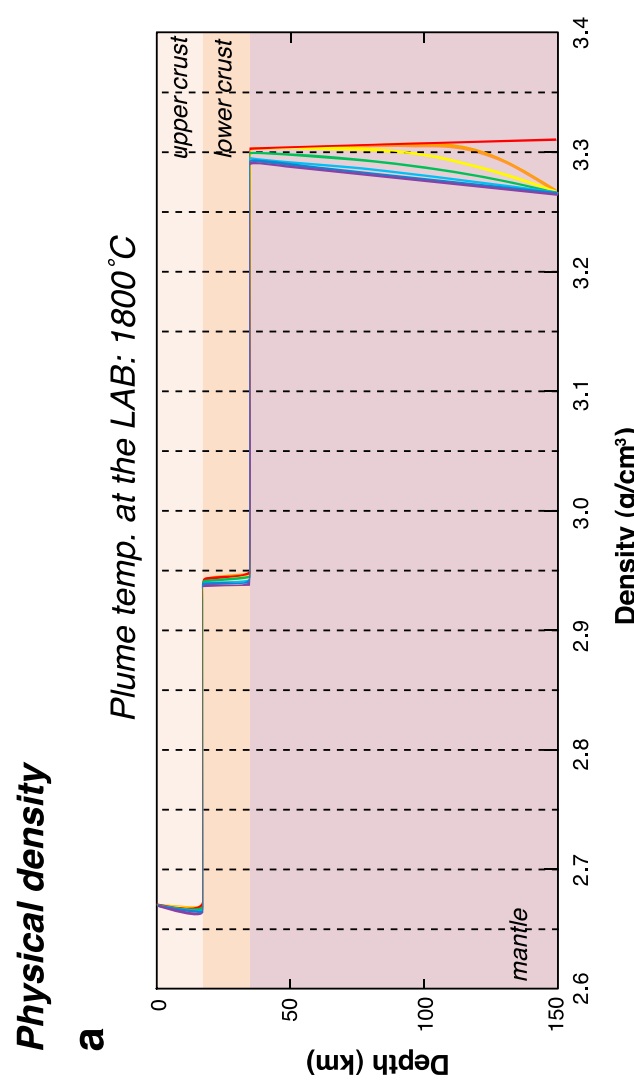

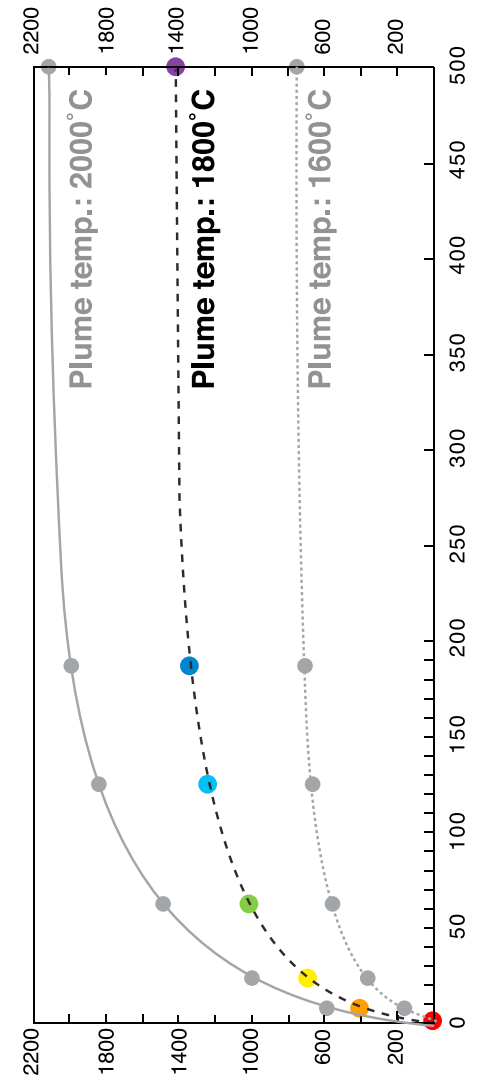

(w) Kydeıbodol
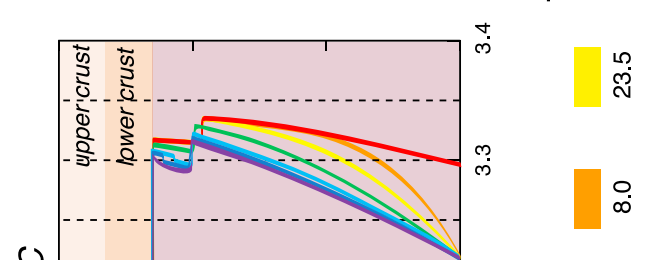

8

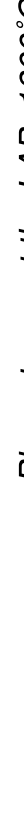

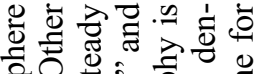

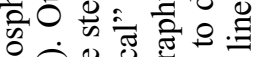

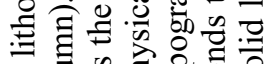

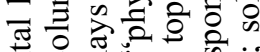

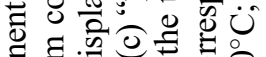
.

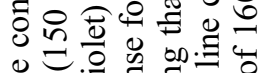

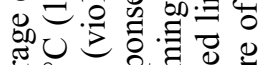

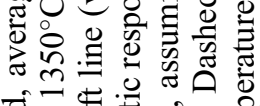

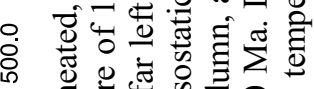
๘ ㄴㅠㅛ

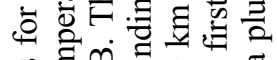

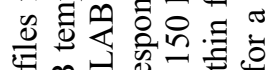

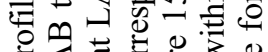

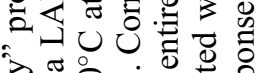
空

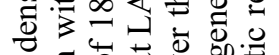

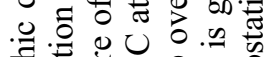

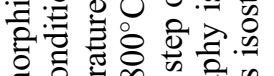
ปี

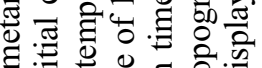

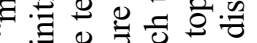
○ิ

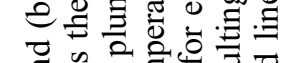

పี

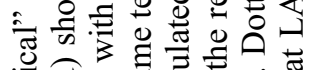

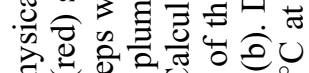

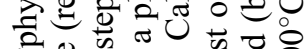

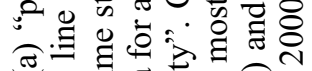
త్త.

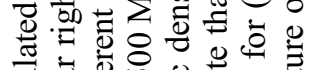

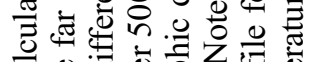

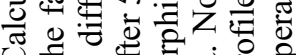
U

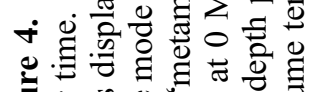
ond \& 


\section{Average lower crust}

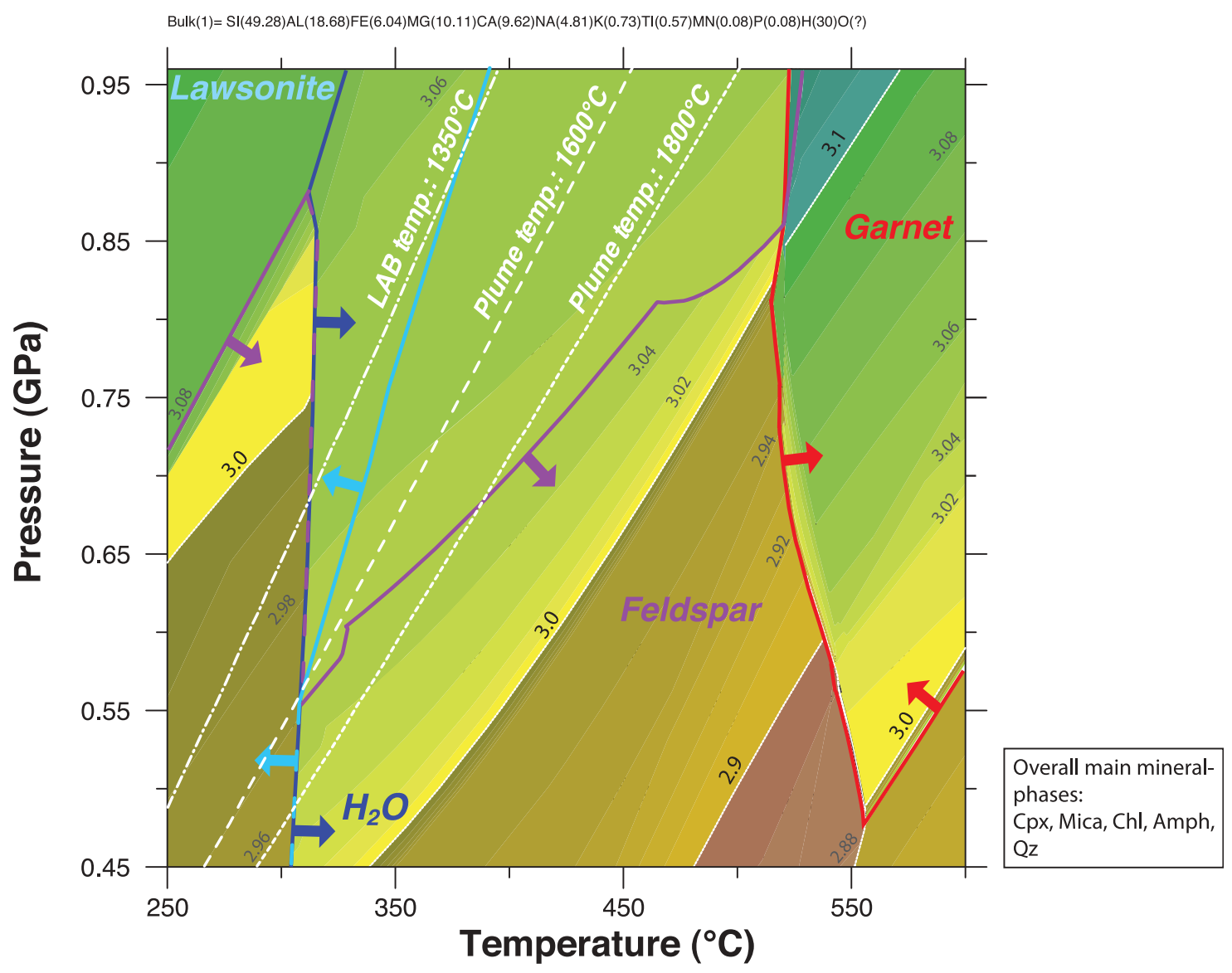

Figure A1. Density isoline plot calculated for a water-saturated lower crust composition from Rudnick and Fountain [1995] by using Domino software [de Capitani and Petrakakis, 2010]. Note first order density jumps at the free fluid-in reaction line (dark blue line labeled with $\mathrm{H}_{2} \mathrm{O}$ ) and the garnet-in reaction line (red line). We simplified the figure, only showing significant mineral-in reactions (colored lines with arrows), influencing the predicted density distribution of the lower crust, because showing mineral assemblages and all reactions render the figure too complex. Mineral abbreviations: Amph - amphibole, Chl chlorite, $\mathrm{Cpx}$ - clinopyroxene, $\mathrm{Qz}$ - quartz.

for plateau formation suggests that plumes would need to remain at the $\mathrm{LAB}$ for at least 130 to $150 \mathrm{Ma}$ to cause a quasiwholesale uplift $(90 \%)$. The uplift process can be divided into three distinct phases (see Figure 4d): (1) an initial phase lasting about $30 \mathrm{Ma}$, during which the plateau is uplifted to approximately half of its final elevation $(\sim 750 \mathrm{~m}) ;(2)$ a second phase when an additional $40 \%$ of the final uplift is reached, lasting 100 to $120 \mathrm{Ma}$; and (3) a final phase with moderate uplift that might last from 120 to $300 \mathrm{Ma}$.

[22] Several studies investigating the uplift history of the South and East African plateaus [e.g., Smith, 1994; Spiegel et al., 2007] concluded that there was dynamic topography on the order of $500 \mathrm{~m}$ during the Cenozoic, caused by convection processes in the mantle [e.g., Ebinger et al., 1989; Nyblade and Robinson, 1994; Lithgow-Bertelloni and Silver, 1998; Behn et al., 2004; Moucha and Forte, 2011]. In this context, Ebinger et al. [1989] postulated that uplift associated with dynamic topography in East Africa cannot explain the entire topographic history of this region. Alternatively, they suggest an additional effect of density variations caused by conductive heat transfer from a mantle plume through the lithosphere. Based on this study, our investigation highlights the importance and the necessary time scales of such lithosphere-plume interactions, thus bridging the gap in knowledge concerning the heat-density relation [Moore et al., 1999; Gueydan et al., 2008] and providing a possibility to apply our model to East African pre-rift topography.

[23] The domal topography of East Africa encompasses a region with an average elevation of $1500 \mathrm{~m}$. However, the timing of plateau uplift (Mesozoic or Cenozoic), the location and spatial extent (e.g., beneath Ethiopia or Kenya/ Tanzania), as well as the number of upper mantle upwellings (one, two or even more), is still subject for ongoing discussion [see Fishwick and Bastow, 2011]. In this context, many studies [e.g., Ebinger and Sleep, 1998; Lithgow-Bertelloni and Silver, 1998; Behn et al., 2004; Koehn et al., 2008] proposed that a thermally uplifted craton is probably realistic and would add to the complexity of the surrounding East African rift system. Nyblade et al. [2000] suggest a mantle plume below the Tanzania Craton at ca. $150 \mathrm{~km}$ depth is 


\section{Average upper crust}

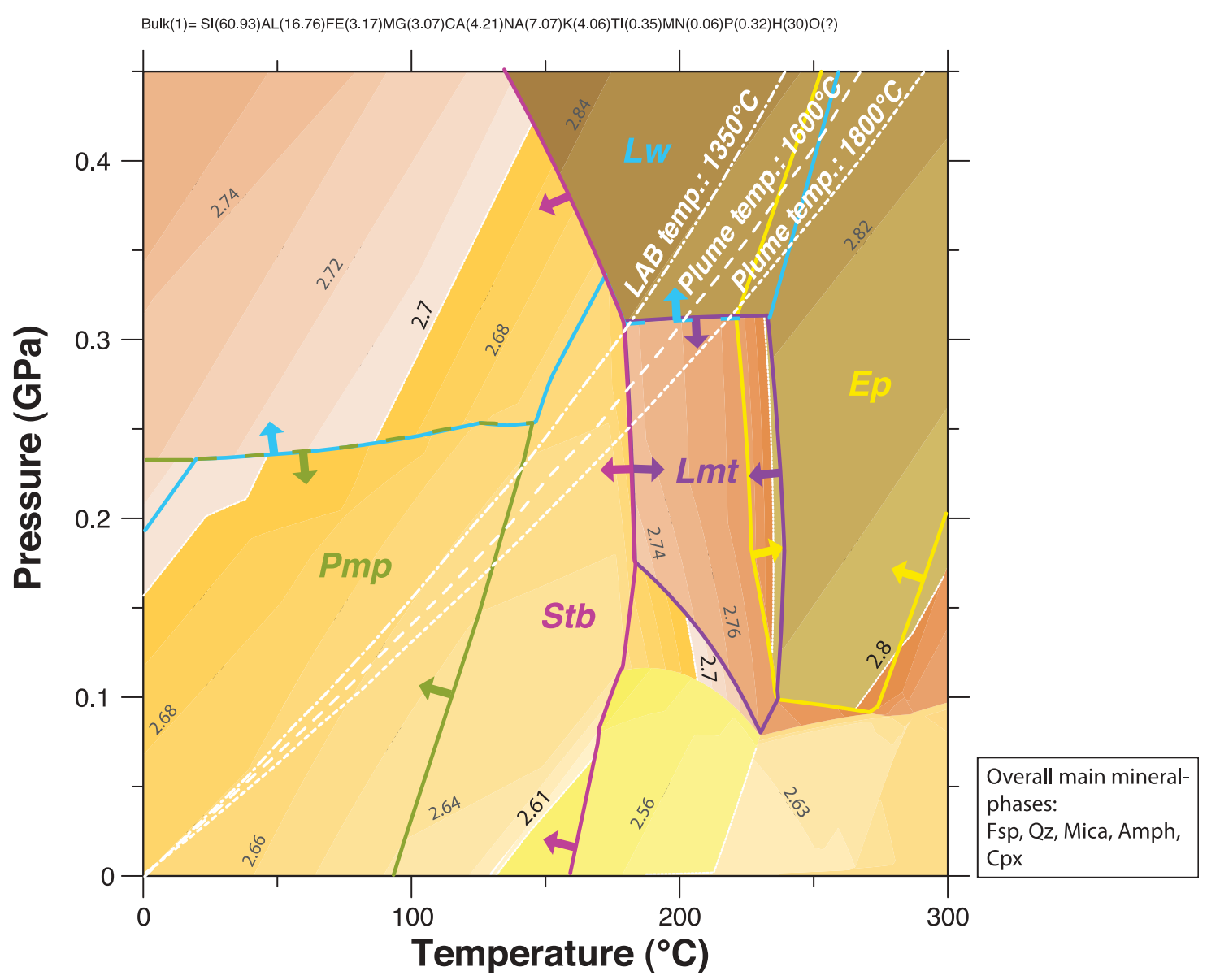

Figure A2. Density isoline plot calculated for a water-saturated upper crust composition from Taylor and McLennan [1985] by using Domino software [de Capitani and Petrakakis, 2010]. Note that below $200^{\circ} \mathrm{C}$ thermodynamic data are not well constrained. However, the density values here seem to be reasonable. The figure clearly shows the onset of metamorphism versus "diagenesis" between 180 and $220^{\circ} \mathrm{C}$. We simplified the figure, only showing significant mineral-in reactions (colored lines with arrows), influencing the predicted density distribution of the upper crust, because showing mineral assemblages and all reactions render the figure too complex. Mineral abbreviations: Amph - amphibole, $\mathrm{Cpx}$ - clinopyroxene, Ep - epidote, Fsp - feldspar, Lmt - laumontite, Lw - lawsonite, Pmp - pumpellyite, Qz - quartz, Stb stilbite.

interacting with the lithosphere. The lithosphere beneath the Tanzanian craton appears to be resistant to alteration throughout time [Weeraratne et al., 2003]. According to Morgan [1983] and Nyblade and Robinson [1994] a hot spot was emplaced beneath the African Superswell (1. East African Plateau, 2. South African Plateau, 3. Southeastern Atlantic Ocean Basin) at approximately $130 \mathrm{Ma}$ and has persisted into the Cenozoic. Using our model, topography of $1200 \mathrm{~m}$ can be accomplished in this time interval, almost reaching the present-day elevation. In contrast, other studies suggest that pre-rift topography started to develop around $35 \mathrm{Ma}$ ago coupled with the onset of volcanism in the northern Kenya Rift [McDougall and Brown, 2009]. This hypothesis of a Cenozoic East African Dome is supported by pronounced sediment influx in the Zambezi Delta [Walford et al., 2005] and vestiges of the basement-cut erosion surface across the region of the Serengeti Plains (Tanzania), which point to a pre-rift elevation of $1500 \mathrm{~m}$
[Burke and Gunnel, 2008]. Also, Smith [1994] suggests a limited crustal uplift $(<1000 \mathrm{~m})$ during the Paleogene and prior to the initiation of volcanism in the central Kenya Rift, based on the investigations on palaeo-drainage reconstructions by King et al. [1972] and King [1978]. Moreover, Wichura et al. [2010b] investigated the phonolitic Yatta lava flow (13.5 Ma) on the eastern margin of the East African Plateau [Lippard, 1973] and showed that this lava flow must have originated on a plateau with a maximum elevation of $1400 \mathrm{~m}$, prior to the onset of rifting at $\sim 11 \mathrm{Ma}$, which then proceeded with the formation of three large half graben basins [Strecker et al., 1990]. As increased sediment production may have corresponded to periods of rapid uplift [Walford et al., 2005], our model predicts an uplift of $\sim 700 \mathrm{~m}$ in a period between $35 \mathrm{Ma}$ and $13.5 \mathrm{Ma}$ (elevation over the first $21.5 \mathrm{Ma}$ in Figure 4d). Adding dynamic topography of $500 \mathrm{~m}$ during the period between $30 \mathrm{Ma}$ and $15 \mathrm{Ma}$ as predicted by the model by Moucha and Forte 
Table A1. Parameters Used to Calculate Geotherms, Lithostatic Pressure and "Physical Density" in This Study

\begin{tabular}{|c|c|c|c|c|}
\hline Parameter & Upper Crust & Lower Crust & Lithospheric Mantle & References \\
\hline Depth $[\mathrm{km}]$ & $0-17.5$ & $17.5-35$ & $35-150$ & Weeraratne et al. [2003] \\
\hline Density at surface ${ }^{\mathrm{a}, \mathrm{b}} \rho_{\mathrm{i}}\left[\mathrm{g} / \mathrm{cm}^{3}\right]$ & 2.67 & 2.946 & 3.316 & calculated with Theriak \\
\hline Heat production ${ }^{\mathrm{c}} A_{0}\left[\mu \mathrm{W} / \mathrm{m}^{3}\right]$ & 1.65 & 0.19 & 0.03 & $\begin{array}{l}\text { Rudnick and Gao [2003]; } \\
\text { Jaupart and Mareschal [2011] }\end{array}$ \\
\hline Conductivity $^{\mathrm{c}} k\left[\mathrm{~W} \mathrm{~m}^{-1} \mathrm{~K}^{-1}\right]$ & 2.5 & 2.4 & 3.3 & $\begin{array}{l}\text { Sobolev et al. [2006]; } \\
\text { Jaupart and Mareschal [2011] }\end{array}$ \\
\hline Thermal diffusivity ${ }^{\mathrm{c}} \kappa\left[\mathrm{m}^{2} / \mathrm{s}\right]$ & $1 * 10^{-6}$ & $1 * 10^{-6}$ & $1 * 10^{-6}$ & Jaupart and Mareschal [2011] \\
\hline Specific heat capacity ${ }^{\mathrm{c}} c_{p}\left[\mathrm{~J} \mathrm{~kg}^{-1} \mathrm{~K}^{-1}\right]$ & 1200 & 1200 & 1200 & Sobolev et al. [2006]; \\
\hline Coefficent of thermal expansion $^{\mathrm{b}} \alpha[1 / \mathrm{K}]$ & $37 * 10^{-6}$ & $27 * 10^{-6}$ & $30 * 10^{-6}$ & Sobolev et al. [2006]; \\
\hline Isothermal compressibility ${ }^{\mathrm{b}} \beta[1 / \mathrm{Pa}]$ & $1.82 * 10^{-11}$ & $1.15 * 10^{-11}$ & $8.33 * 10^{-12}$ & Fowler [2005] \\
\hline
\end{tabular}

${ }^{\mathrm{a}} \mathrm{See}$ equation (2)

${ }^{\mathrm{b}} \mathrm{See}$ equation (3).

${ }^{\mathrm{c}}$ See equation (1).

[2011] to our elevation estimates, would result in a pre-rift topography of $1200 \mathrm{~m}$. However, we obtain the same elevation by calculating over a longer time interval of $130 \mathrm{Ma}$ without adding dynamic topography effects. Taken together, these calculations match well with the observations of Smith [1994], Burke and Gunnel [2008], and Wichura et al. [2010a], and may help to explain pre-rift topography, related to heat from a mantle plume, with dynamic topography being sufficiently high to account for an uplift of $1400 \mathrm{~m}$ prior to rifting [Wichura et al., 2011].

[24] Similar model settings, but poorly constrained prevolcanism uplift histories, are envisaged for the area of the Yellowstone hot spot, including the Columbia River Basalt Plateau and the Snake River Plain in the western U.S. This region constitutes an average elevation of 1500 to $2000 \mathrm{~m}$. Here, related sediment records in the Gulf of Mexico suggest that uplift started around 23.5 Ma in Wyoming [Galloway et al., 2000], before the initiation of Yellowstone plume volcanism at $17.5 \mathrm{Ma}$ [Suppe et al., 1975]. Hill et al. [1992] connected the time interval of $\sim 6 \mathrm{Ma}$ between those events to the rise of a plume head. Assuming conductive heat transfer through the lithosphere caused by a mantle plume as presented in our model, would lead to an uplift of up to $350 \mathrm{~m}$ during a period of $6 \mathrm{Ma}$. We suggest that this is a viable amount of uplift in addition to uplift by mantle dynamics and warming based on removal of the shallow Farallon slab [Humphreys, 1995; Roy et al., 2009], sufficient for production of the sediment record in the Gulf of Mexico [Galloway et al., 2000].

[25] Our model is also applicable to other plume-related plateaus (e.g., Mongolian Plateau) if model parameters are adjusted to the characteristics of regional settings (e.g., lithospheric thickness and heat production rate). Although the reliability of the different thermodynamic databases may be problematic in some cases, their application shows that the presence or absence of certain minerals has an important influence on rock density. Assuming temperatures greater than $1350^{\circ} \mathrm{C}$ can result in melting or changes in rheology of the lithosphere (not considered in this study). Davis and England [1964] showed that forsterite melting occurs at $\mathrm{T}=4.77^{*} \mathrm{P}(=50 \mathrm{kbar})+2171 \mathrm{~K}=2136^{\circ} \mathrm{C}$, temperatures unrealistically high for the LAB. The maximum temperature assumed in our model does not exceed $1800^{\circ} \mathrm{C}$.

[26] Therefore, our model is a step forward in understanding plateau formation processes in geodynamic settings outside of orogens. Our model underscores how the density of the lithosphere varies with depth and it reveals how the combination of chemical composition of rocks, mineralogy, and geothermal gradient all have a significant effect on the density distribution within lithosphere and crust, and ultimately the evolution of anorogenic plateaus. It is an advantage of our method that we perform forward modeling to display the evolution of progressive elevation changes, without the temporal limitation of backward modeled dynamic topography (e.g., the $30 \mathrm{Ma}$ limit of Moucha and Forte [2011]). Finally, our approach shows that the topographic evolution of anorogenic plateaus can only be assessed reliably if metamorphic processes are taken into account. Indeed, density-change models that ignore metamorphic processes will result in a reduced amount of uplift or may require inadequate/unrealistic temperatures (e.g., $2000^{\circ} \mathrm{C}$ ) to explain uplift scenarios.

\section{Appendix A}

[27] This appendix contains more information on rock density (Figures A1, A2, and Table A1).

[28] Acknowledgments. The research was supported by DFG research grant SPP 1257 project 6.2. The authors thank Manfred R. Strecker for very constructive and helpful comments. Furthermore, we like to thank the Graduate School GRK1364 Shaping Earth's Surface in a Variable Environment funded by the German Research Foundation (DFG), co-financed by the federal state of Brandenburg and the University of Potsdam. This manuscript profited from two very constructive reviews by $\mathrm{C}$. Ebinger and an unknown colleague.

\section{References}

Allmendinger, R. W., T. E. Jordan, S. M. Kay, and B. L. Isacks (1997), The evolution of the Altiplano-Puna plateau of the central Andes, Annu. Rev. Earth Planet. Sci., 25, 139-174, doi:10.1146/annurev.earth.25.1.139.

Artemieva, I. M. (2006), Global $1^{\circ} \times 1^{\circ}$ thermal model TC1 for the continental lithosphere: Implications for lithosphere secular evolution, Tectonophysics, 416, 245-277, doi:10.1016/j.tecto.2005.11.022.

Ayalew, D., N. Arndt, F. Bastien, G. Yirgu, and B. Kieffer (2009), A new mantle xenolith locality from Simien shield volcano, NW Ethiopia, Geol. Mag., 146(1), 144-149, doi:10.1017/S0016756808005785.

Behn, M. D., C. P. Conrad, and P. G. Silver (2004), Detection of upper mantle flow associated with the African Superplume, Earth Planet. Sci. Lett., 224(3-4), 259-274, doi:10.1016/j.epsl.2004.05.026.

Berman, R. G. (1988), Internally consistent thermodynamic data for minerals in the system Na2O-K2O-CaO-MgO-FeO-Fe2O3-A12O3-SiO2TiO2-H2O-CO2, J. Petrol., 29, 445-522.

Bousquet, R., B. Goffé, P. Henry, X. Le Pichon, and C. Chopin (1997), Kinematic, thermal and petrological model of the central Alps: Lepontine metamorphism in the upper crust and eclogitisation of the lower crust, Tectonophysics, 273, 105-127, doi:10.1016/S0040-1951(96)00290-9.

Bousquet, R., B. Goffé, C. de Capitani, C. Chopin, X. Le Pichon, and P. Henry (2005), Comment on "Subduction factory 1. Theoritical 
mineralogy, densities, seismic wave speeds and $\mathrm{H}_{2} \mathrm{O}$ contents" by Bradley R. Hacker, Geoffrey A. Abers and Simon M. Peacock, J. Geophys. Res. 110, B02206, doi:10.1029/2004JB003450.

Braun, J., and C. Beaumont (1989), A physical explanation of the relation between flank uplifts and the breakup unconformity at rifted continental margins, Geology, 17, 760-764, doi:10.1130/0091-7613(1989)017<0760 APEOTR $>2.3 . \mathrm{CO} ; 2$.

Brown, G. C., and A. E. Musset (1993), The Inaccessible Earth: An Integrated View of Its Structure and Composition, Chapman and Hall, London.

Burke, K., and Y. Gunnel (2008), The African erosion surface: A continentalscale synthesis of geomorphology, tectonics, and environmental change over the past 180 million years, Mem. Geol. Soc. Am., 201, 1-66.

Chesley, J. T., R. L. Rudnick, and C. T. Lee (1999), Re-Os systematics of mantle xenoliths from the East African Rift: Age, structure, and history of the Tanzanian craton, Geochim. Cosmochim. Acta, 63(7-8), 1203-1217, doi:10.1016/S0016-7037(99)00004-6.

Christensen, N. I., and W. D. Mooney (1995), Seismic velocity structure and composition of the continental crust: A global view, J. Geophys. Res., 100(B6), 9761-9788, doi:10.1029/95JB00259.

Davis, B. T. C., and J. L. England (1964), The melting of forsterite up to 50 kbars, J. Geophys. Res., 69(6), 1113-1116, doi:10.1029/ JZ069i006p01113.

de Capitani, C., and T. H. Brown (1987), The computation of chemical equilibrium in complex systems containing non-ideal solutions, Geochim. Cosmochim. Acta, 51, 2639-2652, doi:10.1016/0016-7037(87)90145-1.

de Capitani, C., and K. Petrakakis (2010), The computation of equilibrium assemblage diagrams with Theriak/Domino software, Am. Mineral., 95, 1006-1016, doi:10.2138/am.2010.3354.

Ebinger, C. J., and N. H. Sleep (1998), Cenozoic magmatism throughout east Africa resulting from impact of a single plume, Nature, 395, 788-791, doi: $10.1038 / 27417$

Ebinger, C. J., T. D. Bechtel, D. W. Forsyth, and C. O. Bowin (1989), Effective elastic plate thickness beneath the East African and Afa plateaus and dynamic compensation of the uplifts, J. Geophys. Res., 94 2883-2901, doi:10.1029/JB094iB03p02883.

Farnetani, C. G. (1997), Excess temperature of mantle plumes: The role of chemical stratification across D", Geophys. Res. Lett., 24(13), 1583-1586, doi:10.1029/97GL01548

Fischer, K. M., H. A. Ford, D. L. Abt, and C. A. Rychert (2010), The lithosphere-asthenosphere boundary, Annu. Rev. Earth Planet. Sci. 38, 551-575, doi:10.1146/annurev-earth-040809-152438.

Fishwick, S., and I. D. Bastow (2011), Towards a better understanding of African topography: A review of passive-source seismic studies of the African crust and upper mantle, Geol. Soc. Spec. Publ., 357(1), 343-371, doi:10.1144/SP357.19.

Fowler, C. M. R. (2005), The Solid Earth: An Introduction to Global Geophysics, 2nd ed., Cambridge Univ. Press, Cambridge, U. K.

Galloway, W. E., P. E. Ganey-Curry, X. Li, and R. T. Buffler (2000), Cenozoic depositional history of the Gulf of Mexico basin, AAPG Bull., 84, 1743-1774

Gueydan, F., C. Morency, and J. Brun (2008), Continental rifting as a function of lithosphere mantle strength, Tectonophysics, 460(1-4), 83-93, doi:10.1016/j.tecto.2008.08.012.

Gurnis, M., J. X. Mitrovica, J. Ritsema, and H. J. van Heijst (2000), Constraining mantle density structure using geological evidence of surface uplift rates: The case of the African superplume, Geochem. Geophys Geosyst., 1(7), 1020, doi:10.1029/1999GC000035.

Hartnady, C. J. H. (1985), Uplift, faulting, seismicity, thermal spring and possible incipient volcanic activity in the Lesotho-Natal Region, SE Africa: The Quathlamba Hotspot hypothesis, Tectonics, 4(4), 371-377, doi:10.1029/TC004i004p00371.

Hattori, K. H., S. Guillot, B.-M. Saumur, M. N. Tubrett, O. Vidal, and S. Morfin (2010), Corundum-bearing garnet peridotite from northern Dominican Republic: A metamorphic product of an arc cumulate in the Caribbean subduction zone, Lithos, 114, 437-450, doi:10.1016/j. lithos.2009.10.010.

Hay, S. I., J. Cox, D. J. Rogers, S. E. Randolph, D. I. Stern, G. D. Shanks, M. F. Myers, and R. W. Snow (2002), Climate change and the resurgence of malaria in the East African Highlands, Nature, 415, 905-909, doi:10.1038/415905a

Henry, P., X. Le Pichon, and B. Goffé (1997), Kinematic, thermal and petrological model of the Himalayas: Constraints related to metamorphism within the underthrust Indian crust, Tectonophysics, 273, 31-56, doi:10.1016/S0040-1951(96)00287-9.

Hetényi, G., R. Cattin, F. Brunet, L. Bollinger, J. Vergne, J. L. Nábelek, and M. Diament (2007), Density distribution of the India plate beneath the Tibetan plateau: Geophysical and petrological constraints on the kinetics of lower-crustal eclogitization, Earth Planet. Sci. Lett., 264(1-2), 226-244, doi:10.1016/j.eps1.2007.09.036.

Hill, R. I., I. H. Campbell, G. F. Davies, and R. W. Griffiths (1992), Mantle plumes and continental tectonics, Science, 256, 186-193, doi:10.1126/ science. 256.5054 .186

Huerta, A. D., A. A. Nyblade, and A. M. Reusch (2009), Mantle transition zone structure beneath Kenya and Tanzania: More evidence for deep-seated thermal upwelling in the mantle, Geophys. J. Int., 177, 1249-1255, doi:10.1111/j.1365-246X.2009.04092.x.

Humphreys, E. D. (1995), Post-Laramide removal of the Farallon slab, western United States, Geology, 23(11), 987-990, doi:10.1130/00917613(1995)023<0987:PLROTF $>2.3$. CO; 2

Jaupart, C., and J. C. Mareschal (2011), Heat Generation and Transport in the Earth, Cambridge Univ. Press, Cambridge, U. K

Jaupart, C., J. C. Mareschal, L. Guillou-Frottier, and A. Davaille (1998), Heat flow and thickness of the lithosphere in the Canadian Shield, J. Geophys. Res., 103, 15,269-15,286, doi:10.1029/98JB01395.

Katayama, I., and J. Korenaga (2011), Is the African cratonic lithosphere wet or dry?, Spec. Pap. Geol. Soc. Am., 478(13), 249-256, doi:10.1130 2011.2478(13)

King, B. C. (1978), Structural and volcanic evolution of the Gregory rift valley, in Background to Fossil Man, edited by W. W. Bishop, Geol. Soc. Spec. Publ., 6, 29-54, doi:10.1144/GSL.SP.1978.006.01.05.

King, B. C., M. J. Le Bas, and D. S. Sutherland (1972), The history of the alkaline volcanoes and intrusive complexes of eastern Uganda and western Kenya, J. Geol. Soc., 128, 173-205, doi:10.1144/gsjgs.128.2.0173.

Koehn, D., K. Aanyu, S. Haines, and T. Sachau (2008), Rift nucleation, rift propagation and the creation of basement micro-plates within active rifts, Tectonophysics, 458(1-4), 105-116, doi:10.1016/j.tecto.2007.10.003.

Le Pichon, X., P. Henry, and B. Goffé (1997), Uplift of Tibet: From eclogites to granulites- implications for the Andean Plateau and the Variscan Belt, Tectonophysics, 273, 57-76, doi:10.1016/S0040-1951(96)00288-0.

Lee, C., and R. Rudnick (1999), Compositionally stratified cratonic lithosphere: Petrology and geochemistry of peridotite xenoliths from the Labait tuff cone, Tanzania, in Proceedings of the 7th International Kimberlite Conference, pp. 503-521, Red Roof, Cape Town, South Africa.

Lippard, S. J. (1973), Plateau phonolite lava flows, Kenya, Geol. Mag. 110(6), 543-549, doi:10.1017/S0016756800037936.

Lithgow-Bertelloni, C., and P. G. Silver (1998), Dynamic topography, plate driving forces and the African superswell, Nature, 395, 269-272, doi: $10.1038 / 26212$

McDougall, I., and F. H. Brown (2009), Timing of volcanism and evolution of the northern Kenya Rift, Geol. Mag., 146(1), 34-47, doi:10.1017/ S0016756808005347.

McKenzie, D. (1984), A possible mechanism for epeirogenic uplift, Nature, 307(5952), 616-618, doi:10.1038/307616a0.

Molnar, P., P. England, and J. Martinod (1993), Mantle dynamics, uplift of the Tibetan plateau, and the Indian monsoon, Rev. Geophys., 31(4), 357-396, doi:10.1029/93RG02030.

Montero Lopez, M. C., F. D. Hongn, M. R. Strecker, R. Marrett, R. Seggiaro, and M. Sudo (2010), Late Miocene-early Pliocene onset of N-S extension along the southern margin of the central Andean Puna Plateau: Evidence from magmatic, geochronological and structural observations, Tectonophysics, 494(1-2), 48-63, doi:10.1016/j.tecto.2010.08.010.

Mooney, W. D., G. Laske, and G. T. Masters (1998), CRUST 5.1: A global crustal model at $5^{\circ} \times 5^{\circ}$, J. Geophys. Res., 103, 727-747, doi:10.1029/ 97JB02122.

Moore, W. B., G. Schubert, and P. J. Tackley (1999), The role of rheology in lithospheric thinning by mantle plumes, Geophys. Res. Lett., 26(8), 1073-1076, doi:10.1029/1999GL900137.

Morgan, W. J. (1983), Hotspot tracks and the early rifting of the Atlantic, Tectonophysics, 94, 123-139, doi:10.1016/0040-1951(83)90013-6.

Morishita, T., S. Arai, and Y. Ishida (2007), Occurrence and chemical composition of amphiboles and related minerals in corundum-bearing mafic rock from the Horoman Peridotite Complex, Japan, Lithos, 95, 425-440, doi:10.1016/j.lithos.2006.09.006.

Moucha, R., and A. M. Forte (2011), Changes in African topography driven by mantle convection, Nat. Geosci., 4, 707-712, doi:10.1038/ngeo1235. Nyblade, A. A., and S. W. Robinson (1994), The African superswell, Geophys. Res. Lett., 21(9), 765-768, doi:10.1029/94GL00631.

Nyblade, A. A., T. J. Owens, H. Gurrola, J. Ritsema, and C. A. Langston (2000), Seismic evidence for a deep upper mantle thermal anomaly beneath east Africa, Geology, 28(7), 599-602, doi:10.1130/0091-7613 (2000) 28<599:SEFADU>2.0.CO; 2

Pascal, C. (2006), On the role of heat flow, lithosphere thickness and lithosphere density on gravitational potential stresses, Tectonophysics, 425(1-4), 83-99, doi:10.1016/j.tecto.2006.07.012.

Pognante, U. (1989), Lawsonite, blueschist and eclogite formation in the southern Sesia zone (western Alps, Italy), Eur. J. Mineral., 1, 89-104. 
Prodehl, C., G. R. Keller, and M. A. Khan (1994), Crustal and upper mantle structure of the Kenya Rift, Tectonophysics, 236, 271-290, doi:10.1016/ 0040-1951(94)90180-5.

Richardson, S. W., and P. C. England (1979), Metamorphic consequences of crustal eclogite production in overthrust orogenic zones, Earth Planet. Sci. Lett., 42(2), 183-190, doi:10.1016/0012-821X(79)90023-2.

Roy, M., T. H. Jordan, and J. Pederson (2009), Colorado Plateau magmatism and uplift by warming of heterogeneous lithosphere, Nature, 459(7249), 978-982, doi:10.1038/nature08052.

Rudnick, R. L., and D. M. Fountain (1995), Nature and composition of the continental crust: A lower crustal perspective, Rev. Geophys., 33(3), 267-309, doi:10.1029/95RG01302.

Rudnick, R. L., and S. Gao (2003), Composition of the continental crust, in Treatise on Geochemistry, vol. 3, edited by H. D. Holland and K. K. Turekian, pp. 1-64, Elsevier, New York, doi:10.1016/B0-08-043751-6/ 03016-4.

Schmidt, M. W., and S. Poli (1998), Experimentally based water budgets for dehydrating slabs and consequences for arc magma generation, Earth Planet. Sci. Lett., 163, 361-379, doi:10.1016/S0012-821X(98)00142-3.

Sepulchre, P., G. Ramstein, F. Fluteau, M. Schuster, J. J. Tiercelin, and M. Brunet (2006), Tectonic uplift and eastern Africa aridification, Science, 313, 1419-1423, doi:10.1126/science.1129158.

Smith, M. (1994), Stratigraphic and structural constraints on mechanism of active rifting in the Gregory Rift, Kenya, Tectonophysics, 236, 3-22, doi:10.1016/0040-1951(94)90166-X.

Sobolev, S. V., A. Y. Babeyko, I. Koulakov, and O. Oncken (2006), Mechanism of the Andean orogeny: Insight from numerical modeling, in The Andes Frontiers in Earth Sciences, edited by O. Oncken et al. pp. 513-535, Springer, Berlin, doi:10.1007/978-3-540-48684-8 25.

Spiegel, C., B. P. Kohn, D. X. Belton, and A. J. W. Gleadow (2007), Morphotectonic evolution of the central Kenya Rift Flanks: Implications for Late Cenozoic environmental change in East Africa, Geology, 35, 427-430, doi:10.1130/G23108A.1.

Strecker, M. R., P. M. Blisniuk, and G. H. Eisbacher (1990), Rotation of extension direction in the central Kenyan rift, Geology, 18, 299-302, doi:10.1130/0091-7613(1990)018<0299:ROEDIT>2.3.CO;2.

Strecker, M. R., R. Alonso, B. Bookhagen, B. Carrapa, G. E. Hilley, E. R. Sobel, and M. H. Trauth (2007), Tectonics and climate of the southern central Andes, Annu. Rev. Earth Planet. Sci., 35, 747-787, doi:10.1146/ annurev.earth.35.031306.140158.

Suppe, J., C. Powell, and K. Berry (1975), Regional topography, seismicity, Quaternary volcanism, and the present-day tectonics of the western United States, Am. J. Sci., 275A, 397-436.
Taylor, S. R., and S. M. McLennan (1985), The Continental Crust: Its Composition and Evolution, 312 pp., Blackwell, Cambridge, Mass.

Thompson, R. N., and S. A. Gibson (2000), Transient high temperatures in mantle plume heads inferred from magnesian olivines in Phanerozoic picrites, Nature, 407, 502-506, doi:10.1038/35035058.

Turcotte, D. L., and G. Schubert (2002), Geodynamics, 2nd ed., 456 pp., Cambridge Univ. Press, New York.

Unglert, K., M. K. Savage, N. Fournier, T. Ohkura, and Y. Abe (2011), Shear-wave splitting, $\mathrm{v}_{\mathrm{p}} / \mathrm{v}_{\mathrm{s}}$, and GPS during a time of enhanced activity at Aso caldera, Kyushu, J. Geophys. Res., 116, B11203, doi:10.1029/ 2011JB008520.

Vidal, O., and B. Dubacq (2009), Thermodynamic modelling of clay dehydration, stability and compositional evolution with temperature, pressure and $\mathrm{H}_{2} \mathrm{O}$ activity, Geochim. Cosmochim. Acta, 73, 6544 6564, doi:10.1016/j.gca.2009.07.035.

Walford, H. L., N. J. White, and J. C. Sydow (2005), Solid sediment load history of the Zambezi delta, Earth Planet. Sci. Lett., 238(1-2), 49-63, doi:10.1016/j.epsl.2005.07.014.

Wallner, H., and H. Schmeling (2010), Rift induced delamination of mantle lithosphere and crustal uplift: A new mechanism for explaining Rwenzori Mountain's extreme elevation?, Int. J. Earth Sci., 99(7), 1511-1524, doi:10.1007/s00531-010-0521-6.

Weeraratne, D. S., D. W. Forsyth, K. M. Fischer, and A. A. Nyblade (2003), Evidence for an upper mantle plume beneath the Tanzanian craton from Rayleigh wave tomography, J. Geophys. Res., 108(B9), 2427, doi:10.1029/2002JB002273.

Weissel, J. K., and G. D. Karner (1989), Flexural uplift of rift flanks due to mechanical unloading of the lithosphere during extension, J. Geophys. Res., 94(B10), 13,919-13,950, doi:10.1029/JB094iB10p13919.

White, R. S., and D. P. McKenzie (1989), Magmatism at rift zones: The generation of continental margins and flood basalts, J. Geophys. Res. 94, 7685-7729, doi:10.1029/JB094iB06p07685.

Wichura, H., R. Bousquet, R. Oberhänsli, M. R. Strecker, and M. H. Trauth (2010a), Evidence for middle Miocene uplift of the East African Plateau, Geology, 38, 543-546, doi:10.1130/G31022.1.

Wichura, H., R. Bousquet, and R. Oberhänsli (2010b), Emplacement of the mid-Miocene Yatta lava flow, Kenya: Implications for modeling long channeled lava flows, J. Volcanol. Geotherm. Res., 198, 325-338, doi:10.1016/j.jvolgeores.2010.09.017

Wichura, H., R. Bousquet, R. Oberhänsli, M. R. Strecker, and M. H. Trauth (2011), The Mid-Miocene East African Plateau: A pre-rift topographic model inferred from the emplacement of the phonolitic Yatta lava flow, Kenya, Geol. Soc. Spec. Publ., 357, 285-300, doi:10.1144/SP357.15. 